\title{
La moneda de la suerte
}

María del Consulolo Figueroa García

—iSuerte? ¿Destino? ¿Infortunio? Cuál de todos es el virus que ataca mi vida y causa esta crónica sensación de que lo mejor sería jalar el gatillo y dejar que esos tres bribones resuelvan lo que se viene. Hace apenas dos semanas la luz brillaba sobre mi futuro. Sólo un golpe de suerte mal dado, un frío estado de ánimo y todo se viene a la basura. Vamos General, ihabla! iDime! ¿Qué debo hacer?

Mientras pensaba en estas cosas, metió una mano en el bolsillo derecho de su chaqueta y sacó el único ahorro con el que contaba. Un peso. Sí, isólo un peso!, que desde hacía más de tres días mantenía como moneda de la suerte. Fríamente la sacó de su cálido nido, la puso frente a sus ojos y con aire retador dijo:

-iVeamos, si en verdad el destino quiere que mi vida se vaya al diablo, que hable ahora o calle para siempre! Y diciendo esto lanzó la moneda al aire, con la apuesta de que si caía cara jalaría del gatillo, y si caía cruz, lo pensaría mejor.

La moneda giraba como bailarina en un chaînés, libremente en el aire, cuando detrás de él escuchó una dulce voz que decía: — ¿Y eso es todo? ¿Dejarás que la suerte decida tu destino, o permitirás que el destino, que no es justamente éste, se imponga y pelearás cara a cara con él?

Sobre sus hombros, sintió unas tibias manos que rozaban su cuello y le hacían sentir que tenía cinco años. Al darse vuelta, en busca de la suave voz, se encontró de frente, como en un viejo sueño, con el rostro de su abuela, quien le miraba como queriendo adivinar desde cuándo este sujeto se hacía llamar su nieto. 
-iMira Adriano!, hace ya 40 años, un hombre fuerte como la guerra, libre de conciencia y en toda su lucidez, perdió lo único que tiene aprecio y dejó que la suerte decidiera su destino. Era un hombre de palabra; pero también, un hombre de apuestas. Una mañana como ésta, tibia y llena de luz, regresó del cuartel y se encerró en esta biblioteca. Pasó largo rato caminando de un extremo al otro de la habitación con la mirada puesta en la punta de los zapatos. Nada podía hacer yo del otro lado de la trinchera, ya que, como era costumbre, cuando le acaecía un problema solía entrar en su madriguera, cavilar un poco y salir después de largo rato con la solución en la punta de la mirada. Pero ese día, ese infortunado día, no fue así. Entró con el cuerpo lleno de vida y salió vacío, con los ojos sin brillo y el ceño fruncido, con ese rasgo de coraje de quien ya nada puede hacer. Me retiré a mis deberes y, justo cuando las cazuelas hervían sobre la estufa, escuche un estruendo. Un relámpago que me atravesó el corazón. Junte las manos y supliqué que lo que había escuchado no fuera verdad, pero la realidad se impone a cualquier verdad que uno suplica. Corrí como loca desde la cocina hasta este lugar, abrí la puerta y vi su cuerpo arrojado sobre la silla, la pistola tirada en el suelo apuntando a una moneda de a peso, con la cara al techo, como esa que sostienes entre los dedos. Sobre su escritorio encontré esta carta.

\section{Querida Agustina,}

Perdona la ofensa y el daño que te causo. Este día, el destino decidirá por los dos. Hace unas horas, en el cuartel, una estúpida apuesta hizo que un hombre perdiera la vida. Era un hombre de familia y buena persona. Con nadie se metía y a nadie hacía daño. Su único pecado fue haberse cruzado en el camino del compadre Celedonio, cuando éste iba hacía mi oficina. La grave ofensa fue que, el ingrato, no fue capaz de dejar sus labores para cuadrarse y darle la bienvenida como a todo militar de rango. Yo, burlón como siempre, le dije: —No se preocupe, compadre, en este mismo momento lo mando fusilar. El compadre respondió con aire retador: - No es necesario, compadre, mejor dejémoslo al destino. Y, lanzando al cielo la moneda, que encontrarás derribada en este suelo, continuó: —Si es cara, lo fusilamos. Y así fue, la moneda cayó mostrándonos la seria imagen de don Benito Juárez. Como soy hombre de palabra, hice que en ese momento fusilaran al desgraciado aquél. Así que he decidido que la única forma de saldar esta deuda es dejar que el destino pague por mí. Si la suerte no me favorece sólo espero tu comprensión y el perdón de Dios.

Armando Arteaga

General de la $5^{\circ}$ División 
Se escuchó un tintineo sobre la baldosa cuando Adriano recordó que su abuela se encontraba en ese momento en el quirófano del hospital militar y que había prometido a su madre estar ahí para apoyarlas. Salió corriendo sin hacer caso de la moneda que bailaba sobre su costado en espera de caer por completo sobre el suelo.

Cuando se cerró la puerta de la biblioteca, tras los pasos de Adriano, la moneda por fin cayó completamente, mostrando el segundo anillo del calendario azteca con un gran uno en su centro.

María del Consuelo Figueroa García. Mexicana. Médico Veterinario Zootecnista con Maestría y Doctorado en Ciencias Veterinarias por la Universidad Nacional Autónoma de México (UNAM), México. Licenciada en Creación Literaria por la Universidad Autónoma de la Ciudad de México (UACM), México, y estudiante de Derecho por la UNAM. Cuenta con 18 publicaciones científicas en el área de la fisiología y la bioquímica y más de 80 en congresos especializados. En el área de la creación literaria ha publicado "El día que se perdió la vaca" (Letralia, 2020); "Gatos verdes en la luna" (2015, Revista C2. Ciencia y Cultura), y "La locura del Quijote de la Mancha" (2015, Revista C2. Ciencia y Cultura) Incluida en La república en la voz de sus poetas. Antología 2012, XX Encuentro Internacional de Mujeres Poetas en el País de las Nubes, editado por el Centro de Estudios de la Cultura.

(D): 0000-0003-1985-0825 